\title{
Code Mixing Strategies in BLACKPINK's Album
}

\author{
Sri Mulyati ${ }^{*}$, Purwani Indri Astuti ${ }^{2}$, Arin Arianti $^{3}$ and Azalia Noviana ${ }^{4}$ \\ 1,2,3English Department, Universitas Veteran Bangun Nusantara Sukoharjo, Indonesia and ${ }^{4}$ SMA Negeri III \\ Kabupaten Tangerang,Indonesia \\ *smlyaa24@gmail.com
}

\begin{abstract}
This research described the application of code mixing in Blackpink's album. The study aimed to determine the types of code mixing that appeared in several songs of the album and to describe the functions of respective expressions that use code mixing. This research implemented a descriptive-qualitative method, in which documentation and content analysis were deployed for the data collection. To ensure the trustworthiness of the study, a theoretical triangulation was utilized to cross-check the collected data. In this research, various theories regarding code mixing facilitated the cross-checking, including those by Crystal, Gumperz, and Marasigan. The data analysis adopted Miles and Huberman's interactive model, which consisted of data collection, data reduction, data display, and conclusion. The findings revealed 37 data that were classified into Intra Sentential Mixing mixing, 19 data into Intra Lexical Mixing, and a single datum that indicated the Change of Pronunciation. The Intra Sentential Mixing appeared as the most dominant type of all the data, code mixing features reflected various functions, including quotation, addressee specification, repetition, interjection, message qualification, personalization and objectivization, and personal expression. Based on the analysis, personalization and objectivization, addressee specification, and message qualification appeared as the top three most dominant functions of code mixing.
\end{abstract}

Key words: Blackpink's album, code mixing, song lyric.

\section{Introduction}

The fundamentals of Foreign language is Communicating. Communication plays a significant role in people's lives in which they use communication with their families, friends, and other people. Moreover, communication is more meaningful between teachers and students in class. With communication, we know all the aspects of each other like business, culture, and education. Communication is important to effective skills in the qualification, which is that the culture can change the society to learn multiplication language, like the increased ability of students to communicate between cultures. [1]. Language and connection to learn the language in the world. With available communication, people can make relations with other people in the world [2]. However, in people's lives communication is used every day as a tool for communication with others. On the other hand, communication has a good role in various aspects, which is education where a teacher can communicate with students in class. the same as a purpose in education as to how the student speaks the language to become effective, including connecting classmates, large class and the situation class [3]. 
In learning a language, communication is very important. Students have that skill to influence the process of student communication in the second language. By this there one of the purposes is knowing what factors can influence the student learning English. According to Zeng, there are some influences that are found; the classroom, teacher sport, student confidence [4]. Lee and Hsieh stated that there are some factors that can improve student communication which include classroom involvement, motivation and patience [5]. However, there are some found that there are students who still have to communicate with people or not speak in class. In this era, most students still have the attitude to not communicate with their friends in class, which is caused by some factors like nervousness, or afraid to communicate.

Al-Murtadha \& Feryok said that when students learn English, there are two things they communicate [6]. The first is the student has the motivation to speak and also the second student does not have the motivation that means they just silent or disappear when the teacher gives the opportunity to communicate in class, Adding by Fukuta, two communications are when a student chooses to not communicate their call is UWTC, and the second is the student has a willingness to communication call is WTC [7]. One the issue in teachers is students have the willingness and unwillingness to communicate in English foreign language (EFL ) in the classroom like they said that that is inclusive of influence by study and a feat in student learning English unwillingness to communicate and then Zarrinabadi conducted the study about willingness to communicate [8]. He found the student difficult to explain their knowledge to the second language, things that affected the student not comfortable, or, the topic is unfamiliar, the size they did not have an interlocutor to support their communication as second language. Then the circle can also influence factors of unwillingness to communicate, in the things in communication-related with how well we speak to convey the message to people. With a good speaker, someone can understand what they said, but sometimes someone or student feels scared about communication in foreign language, particularly speaking they have some detention in themselves or unwillingness to communicate with others. In most of Asia learning a second language or foreign language. the students seldom describe something pasif that make them unwillingness to communication English foreign language in class.[8]

\section{Methodology}

This study used a descriptive-qualitative research method. A qualitative research regards to qualitative design and strategy in research [11]. Qualitative research is also a method of the research that is based on the philosophy of post positivism use to research the natural condition of object [12]. The characteristics of this research method include the natural setting, the researcher as the key instrument, the research has inductive data analysis and the perspective is theoretical. Thus, this research applied a descriptive-qualitative method.

The source data of this research was used song lyrics of Blackpink's album. It consists of seventeen songs and has been distributed globally. Meanwhile, the data in this research were collected from words, phrases, clauses, and sentences between Korean-English languages in song lyrics of Blackpink's album. Dealing with this research, in collecting the data, the researcher used documentation and content analysis. Documentation is intended to obtain the data directly from song lyrics where the researcher collected from K-pop lyric application.

In this study, the researcher took the data from Blackpink's album. Collecting the data focused on the code mixing utterance. Furthermore, the researcher used library research as research approach. Because, the researcher was not only collecting the data but also analyzed the data to get the research's result. Therefore, the researcher applied content analysis. Content analysis is performed on style of human communication, as well as newspapers, books, perosnal journals, official document, music, and video tapes of human interactions [6]. The researcher used content analyzed in the technique of data analysis because the researcher analyzed the music and read the transcript that the researcher had written. Library research is used to collect and obtain the data from written material that needed by the researcher that has been published [13].

The numeral 001, 002, 003...are used to show the order of the data number. The alphabetic capital letters are used to classify the types of code mixing. The numeral 1, 2, 3, 7, $9 \ldots$ are used to show the order songs of code mixing in the lyrics song of Blackpink's album. To differentiate from the number of data, this study gives the capital letter $\mathrm{S}$. it means that letter $\mathrm{S}$ is the number of the song by Blackpink. Those are can be put together into sentences in the example below: 001/ISM/ S.1 means the first data type intra sentential mixing in the song which is located in the first part song lyric of 'Boombayah' by Blackpink.

In this research, the main instrument is the researcher. As a human instrument, the researcher functioned in deciding the focus, collecting the data, analyzing the data, paraphrasing the data and making conclusion. The supporting instruments were the note, pen, book and laptop.

The validity of the data is needed in qualitative research. The researcher applied triangulation technique to support the validity of the data. According to Denzin and Lincoln in [12] propose that triangulation technique is divided into four types. They are data triangulation, investigator triangulation, theory triangulation and methodological triangulation. Thus, the researchers took triangulation of theory to examine the validity of the data. The researcher uses the classification of code-mixing that involves the transfer of linguistic elements by Crystal [14] and adds 
Table 1. The Frequency of Code Mixing Types in Blackpink's Album

\begin{tabular}{llc}
\hline No & Types of Code Mixing & Occurence \\
\hline 1. & Intra-sentential mixing & 37 \\
2. & Intra-lexical mixing & 19 \\
3. & Involving a change of pronunciation & 1 \\
\hline & $\quad$ Total & 57 \\
\hline
\end{tabular}

Table 2. The Frequency of Code Mixing Types in Blackpink's Album

\begin{tabular}{llc}
\hline No & Types of Code Mixing & Occurence \\
\hline 1. & Quotation & - \\
2. & Addressee Specification & 12 \\
3. & Repetition & 1 \\
4. & Interjection & 2 \\
5. & Message Qualification & 12 \\
6. & Personalization and Objectivication & 22 \\
7. & Facility of Expression & 8 \\
\hline & & Total \\
\hline
\end{tabular}

the theory that shows several reasons of code-mixing by Gumperz [15]. It means that the researcher used some theoretical position in interpreting data.

Last, to analyze the data, the researcher used Miles and Huberman's theory of Interactive Model. In this model have three steps : Reduction, Data Display and Verification or Conclusion [16]. Thus, the data analysis was the process of systematically search and arranged the data obtained by organizing data into categorized and making conclusion that can be understood.

\section{Findings and Discussion}

Based on the data analysis, the data in this research based on the type and the function of code mixing. The types of code mixings are intra-sentential mixing, intra-lexical mixing, and involving a change of pronunciation. Furthermore, the researcher also analyzes the function of Code-Mixing found in the data based on the theory of Marasigan. There are seven functions proposed by Marasigan, including: 1) Quotation, 2) Address Specification, 3) Repetition, 4) Interjection, 5) Message Qualification, 6) Personalization and Objectivization, and 7) Facility of Expression [16].

The researcher presented the data found in the research. The data from English-Korean languages that found by researcher in the song lyrics of Blackpink's album.

\section{Code Mixing Types}

\section{Intra-Sentential Mixing Type}

Code mixing is the phenomenon of mixing two or more languages are used at same time. Code mixing is divided into three types. The one type of code mixing is intra-sentential mixing. Intra-sentential mixing is the type of code mixing occurs in a phrase, clause or a sentence boundary. The first types of code mixing is intra-sentential mixing which found in title song Boombayah, Whistle, Playing With Fire, Stay, As If It's Your Last, Ddu-Du-Ddu-Du, Forever Young, Really, See You Later, How You Like That, Lovesick Girl, Pretty Savage, and You Never Know. In these songs above the researcher can be identified as an intra-sentential mixing type of code mixing.

Example 1. 004/ISM/S.1

(Boombayah by Blackpink, a part of Lisa)

Chyeoda bodeun maldeun I wanna dance

English Translation:

Do not care if look or not, I wanna dance

Indonesian Translation:

Tidak peduli apakah kamu melihat atau tidak, aku hanya ingin menari

From part of lyric above it shows the clause 'I wanna dance' which mixes Korean with to the English language. This condition can be called the process of code mixing and can be analyzed the lyric has types of intra-sentential mixing. 
(Whistle by Blackpink, a part of Jennie)

Modeun namjadeuli nal maeil check out

English Translation:

Every guy checks me out every day

Indonesian Translation:

Setiap pria mengecekku keluar setiap hari

From part of lyric above it shows the phrase 'check out' which mixes Korean with to the English language. This condition can be called the process of code mixing and can be analyzed the lyric has types of intra-sentential mixing.

\section{Intra-Lexical Mixing Type}

Code mixing is the phenomenon of mixing two or more languages are used at same time. Code mixing is divided into three types. The one type of code mixing is intra-lexical mixing. Intra-lexical mixing is the type of code mixing occurs in a lexical or word boundary. The second types of code mixing is intra-lexical mixing which found in title song Boombayah, Whistle, Playing With Fire, Stay, As If It's Your Last, Ddu-Du-Ddu-Du, Forever Young, See You Later, and Pretty Savage. In these songs above the researcher can be identified intra-lexical mixing type of code mixing.

Example 3. 014/ILM/S.9

(See You Later by Blackpink, a part of Jennie)

Bin kkangtong gateun ni sorry

English Translation:

Your sorry rings like an empty can

Indonesian Translation :

Seperti kaleng kosong ya, maaf anda

From part of lyric above it shows the word sorry which mixes Korean with to the English language. This condition can be called the process of code mixing and can be analyzed the lyric has types of intra-lexical mixing.

Example 4. 018/ILM/S.15

(Pretty Savage by Blackpink, a part of Rose)

Ulin yeppeujanghan savage

English Translation:

We are pretty savage

Indonesian Translation:

Kami sangat biadab

From part of lyric above it shows the word 'savage' which mixes Korean with to the English language. This condition can be called the process of code mixing and can be analyzed the lyric has types of intra lexical mixing.

\section{Pronunciation Change Type}

Involving a change of pronunciation is the type of code mixing it is occurs at the phonological or pronunciation level.The third types of code mixing is change of pronunciation which found in title song Stay. In the song above the researcher can be identified involving a change of pronunciation type of code mixing because part of the song lyrics above occurs in phonological or pronunciation level. The fewest number of code mixings in the song lyrics of Blacpink's album is the types of a change of pronunciation attains 1 data.

Example 5. 001/ICP/S.4

(Stay by Blackpink, a part of Rose)

Neol darmeun deuthan seulpeun mellodi

English Translation :

This sad melody resembles you

Indonesian Translation :

Melodi sedih yang tampaknya menyerupai anda

From part of lyric above it shows the word 'mellodi' written in the Korean word. It should depend on English word 'melody'. This condition can be called the process of code mixing and can be analyzed if the lyric has types of intra lexical mixing.

The discussion starts with the types of code mixing and then the function of it. In this section, The discussion starts from the first function of code mixing until the last function of code mixing, as follow: 


\section{Code Mixing Functions}

\section{Quotation}

The highlight defined from quotation is a truth and used to maintain the authenticity of the message. After analyzing the data, there was not found the main data with the quotation's function. Because in the lyrics song was wrote without quote by someone or other speaker.

\section{Addressee Specification}

Addressee specification is used to interact between the members of the speech but also to admit the language behavior include the individual preference and the role relation of the members of the speech.

\section{Example 1. 012/ISM/S.4}

Geojit gateun sesang sok yuilhan truth it's you

English Translation:

In this world that is a lie the only truth, it's you

Indonesian Translation:

Didunia yang salah ini satu-satunya kebenaran itu anda

Because after being translate in English and Indonesia languange, the word 'you' in the lyric song showed address specification. In indonesian language, the word 'anda' in its used to greet the speech partner (greeting words) and can be used to refer to the speech partners (reference words). It is clarify the lyric has a meaning to give a message directly to someone.

\section{Repetition}

The function repetition in code mixing is a message to repeated in the other code aimed to clarify what the speaker said, strengthen or emphasize the message, or mark the joke.

\section{Example 2. 008/ISM/S.2}

Every day all day nae gyeoteman isseojwo zoom zoom

English Translation :

Every day all day Only stay by my side, zoom zoom

Indonesian Translation :

Setiap hari sepanjang hari hanya ada disisiku zoom zoom

Because after being translate in English and Indonesia languange, the phrase 'every day all day' in the lyric song showed the repetition. In Indonesian language, the sentence 'setiap hari sepanjang hari' its showed the repetition. The word shows an affirmation of the repeated word to give rise to certain connotations. It is clarify the lyric has a meaning to strengthen what singer said and emphasize the message for someone.

\section{Interjection}

The function interjection in code mixing used to change the interaction from the 'they' to the 'we' code. It means that the speakers mix the code in order to utter the interjection. Interjection expresses strong emotions.

Example 3. 021/ISM/S.7

Nae diamond-cheoreom we'll shine together

English Translation :

Like my diamond, we'll shine together

Indonesian Translation :

Seperti berlian, kami akan bersinar bersama

The subject 'We' in the lyric song showed the change the interaction from the 'they' to the 'we' code. In Indonesian language, the word 'kita' is used when the person being spoken to is included, while the word 'kami' is used when the person being spoken to is not included. It means that the speakers mix the code in order to utter the interjection.

\section{Message Qualification}

The function of message qualification in code mixing used to qualify a previous message which the speaker believed would be better understood in other language.

Example 4. 004/ISM/S.1

Chyeoda bodeun maldeun I wanna dance

English Translation :

Do not care if look or not, I wanna dance

Indonesian Translation : 
Tidak peduli apakah kamu melihat atau tidak, aku hanya ingin menari

After being translate in English and Indonesia languange, the clause 'I wanna dance' is written in English language so that the message the singer want to convey is more easily understood by global fans or $\mathrm{K}$-pop music in around the world. Indonesian people is often used the word 'dance' in daily conversation. So, the message of the lyric easily to understand even in English language. It is clarify the lyric has a meaning that gives a message qualification for the message could be clear explanation and easy to understand.

\section{PectioPersonalization and Objectivization}

The function of personalization and objectivization is the code contrast here seems to relate to such thing as: the degree of speaker involvement in, or distance form, a message; whether a statement reflects personal opinion, feeling, whether it refers to specific instance, or whether it has the status of generally known fact.

Example 5. 006/ISM/S.2

Modeun namjadeuli nal maeil check out

English Translation :

Every guy checks me out every day

Indonesian Translation :

Setiap pria mengecekku keluar setiap hari

After being translate in English and Indonesia languange, we know the fact that the singer state if every guy checs me out every day. In Indonesian language, the sentence 'mengecekku keluar setiap hari' used to state that the singer has a confident about her popularity around the boys. It is clarify the lyric has a meaning that gives a personalization and objectivization about it.

\section{Facility of Expression}

The function of facility of expression is facility of expression is a function 'where the shift ... can only be interpreted as difficulty in finding the right words at the time of speaking or writing or merely as a sign of the subject's lack of familiarity with the style he is using'

Example 6. 007/ISM/S.2

Hold up amu mal haji ma just whistle to my heart

English Translation :

Hold up. Don't say anything, just whistle to my heart

Indonesian Translation :

Tahan. Jangan mengatakan apapun, cukup bersiul untuk hatiku

After being translate in English and Indonesia languange, we know that difficulty in finding the right words at the time of speaking or merely as a sign of the subject's lack of familiarity with the style the singer is using. Then, in lyrics song the singer ask to , 'just whistle to my heart'. It is clarify the lyric has a meaning about a facility of expression to emphasis the message to be easily understanding.

\section{Conclusion}

The researcher concludes the research of code mixing in the song lyrics of Blackpink album, as follows: the first, the researcher classified the data into three types of code mixings [14]. The whole data found in Blackpink's album are 57. It can be classified into intra-sentential mixings as many as 37 data, intra-lexical mixing as many as 19 data, and involving a change of pronunciation with only 1 data. The highest number types of code mixings in Blackpink album is intra-sentential mixings and the fewest number type of code mixing is involving a change of pronunciation.

Second, the researcher used Marasigan theory to analysis the function of the data. Marasigan theory has seven functions of code mixing, namely: quotation, address specification, repetition, interjection, message qualification, personalization and objectivization, the last is facility of expression. Each data from the song lyrics of Blackpink's Album has its own function. The most dominant function of code mixing in the song lyrics of Blackpink's album is personalization and objectivization with total data is 22 data. Then, address specification and message qualification with total data is 12 data. Furthermore, the fewest number is interjection with 2 data and repetition only has 1 data.

\section{Acknowledgements}

The researchers express gratitude to the committee of the Annual Seminar on English Language Studies (ASELS) 2021 for providing a relevant room of discussion regarding this research topic. The researchers also thank the Association of Muslim Community in ASEAN (AMCA) for facilitating the publication. 


\section{References}

[1] R. N. Ria, Code-Switching and Code Mixing in the Lyrics of Bondan Prakoso Featuring Fade 2 Black's Song. Yogykarta: State Islamic University Sunan Kalijaga, 2016.

[2] D. S. Wahyuni, Code Mixing in Song Lyrics of Goblin Korean Drama Album. Surakarta: State Islamic Institute of Surakarta, 2018.

[3] K. Zakiah, et al., 'Menjadi Korean di Indonesia: mekanisme perubahan budaya Indonesia-Korea'. MediaTor, vol. 12, 1, pp. 90-101, 2019. Available: https ://ejournal.unisba.ac.id/index.php/mediator/article/view/3979.

[4] E. Jocelin, T. Tryana, "Code mixing and code switching in a Korean song lyric," Linguistics and Applied Linguistics, vol. 1, 2, pp. 47-52, 2019. Available: http://dx.doi.org/10.32493/ljlal.v1i2.5127

[5] F. K. Simbar, "Fenomena konsumsi budaya Korea pada anak muda di Kota Manado," Holistik, vol. 10, 18, pp. 1-20, Dec 2016. Available: https ://ejournal. unsrat.ac.id/index.php/holistik/article/view/14226.

[6] A. Sukrisna, An Analysis of Using Code Mixing on Atta Halilintar's Video Youtube Channel. Lampung: Raden Intan State Islamic University, 2019.

[7] R. Wardaugh, An Introduction to Sociolinguistics, Malden, Mass., USA: Blackwell Publishing, 2006.

[8] A. Arianti, "A study of students' efforts to improve the ability in English," Surakarta English and Literature, vol. 4, 1, pp. 1-10, Sep 2021. Available: https://ejournal.unsa.ac.id/index.php/selju/article/view/581

[9] Giyatmi, Ratih Wiyava, "Word formation of messaging applications found in Play Store," Linguistics and Literature, vol. 5, 1, pp. 92-109, Mar 2021. Available: https://lirejournal.ubb.ac.id/index.php/LRJ/article/ view/106

[10] J. Holmes, An Introduction to Sociolinguistics, $4^{\text {th }}$ ed. London and New York: Routledge, 2013.

[11] J. W. Creswell, Research Design Qualitative, Quantitative, and Mixed Methods Approaches, $4^{\text {th }}$ ed. London: SAGE Publications Inc, 2014.

[12] Sugiyono, Metode Penelitian Kuantitatif, Kualitatif, dan R\&D,23 ${ }^{\text {rd }}$ ed. Bandung: Alfabeta, 2016

[13] G. I. Putri, An Analysis on The Figurative Language in Adele's Song Lyrics of '21' Album. Malang: Muhammadiyah University, 2012.

[14] P. I. Astuti, V. U. Pratiwi, "The implementation of teaching translation by using comment exercise method," International Conference on Linguistics and Translation Studies, Surakarta, 2016, pp. 299-307. Available: https : //pasca.uns.ac.id/s2ilmulinguistik/publikasi/icolts/.

[15] J. J. Gumperz, Discourse Strategies in Interactional Sociolinguistics 1. New York: Cambridge University Press, 1982.

[16] A. Rosyidha, An Analysis on The Functions of Code-Switching and Code Mixing Found in The Written Form of Celebgram Interactions. Salatiga: State Institute for Islamic Studies (IAIN), 2017. 